\title{
More efficient aboveground nitrogen use in more diverse Central European forest canopies
}

\author{
Martin T. Schwarz ${ }^{* \dagger}$, Sebastian Bischoff $f^{\ddagger}, \quad$ Stefan Blaser ${ }^{\S}$, Steffen Boch ${ }^{\S}$,

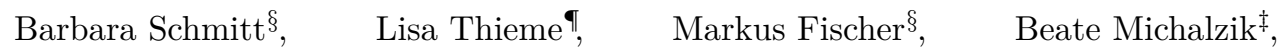 \\ Ernst-Detlef Schulzell, Jan Siemens $\$$ Wolfgang Wilcke**
}

Published under Copyright@ of Elsevier B.V. 2013:

Schwarz, M. T., Bischoff, S., Blaser, S., Boch, S., Schmitt, B., Thieme, L., Fischer, M., Michalzik, B., Schulze, E.-D., Siemens, J. \& W. Wilcke. (2014). More efficient aboveground nitrogen use in more diverse Central European forest canopies. For. Ecol. Manage. 313: 274-282. doi:10.1016/j.foreco.2013.11.021.

\footnotetext{
Abstract

We hypothesized that biodiversity improves ecosystem functioning and services such as nutrient cycling because of increased complementarity. We examined $\mathrm{N}$ canopy budgets of 27 Central European forests of varying dominant tree species, stand density, and tree

*Corresponding author: M.T.Schwarz@outlook.com

${ }^{\dagger}$ University of Berne, Institute of Geography, Hallerstrasse 12, 3012 Berne, Switzerland

${ }^{\ddagger}$ Friedrich Schiller University of Jena, Institute of Geography, Löbdergraben 32, 07743 Jena, Germany

$\S$ University of Berne, Institute of Plant Sciences and Botanical Garden, Altenbergrain 21, 3013 Berne, Switzerland

『Rheinische Friedrich Wilhelms University of Bonn, Institute for Crop Science and Resource Conservation, Division Soil Science and Soil Ecology, Nussallee 13, 53115 Bonn, Germany

"Max Planck Institute for Biogeochemistry, HansKnöll-Strasse 10, 07745 Jena, Germany

** Karlsruhe Institute of Technology (KIT), Institute of Geography and Geoecology, Kaiserstrasse 12, 76131 Karlsruhe, Germany
}

and shrub species diversity (Shannon index) in three study regions by quantifying bulk and fine particulate dry deposition and dissolved below canopy $\mathrm{N}$ fluxes. Average regional canopy $\mathrm{N}$ retention ranged from $16 \%$ to $51 \%$, because of differences in the $\mathrm{N}$ status of the ecosystems. Canopy $\mathrm{N}$ budgets of coniferous forests differed from deciduous forest which we attribute to differences in biogeochemical $\mathrm{N}$ cycling, tree functional traits and canopy surface area. The canopy budgets of $\mathrm{N}$ were related to the Shannon index which explained $14 \%$ of the variance of the canopy budgets of N, suggesting complementary aboveground $\mathrm{N}$ use of trees and diverse understorey vegetation. The relationship between plant diversity and canopy $\mathrm{N}$ retention varied among regional site conditions and forest types. Our results suggest that the traditional view of belowground complementarity of nutrient uptake by roots in diverse plant communities can be transferred to foliar uptake in forest canopies.

\section{Keywords}

- Terrestrial nitrogen cycling

- Nitrogen deposition

- Canopy N retention

- Ecosystem functioning

- Complementarity

- Biodiversity Exploratories 


\section{Introduction}

Ecosystem functioning comprises processes, services, and stability (Millennium Ecosystem Assessment 2005). Pools and fluxes of water, carbon and nutrients such as nitrogen $(\mathrm{N})$ within and between ecosystems are provisioning, regulating and supporting ecosystem services, respectively, because they feed back to food production and non-food resource supply such as timber (Millennium Ecosystem Assessment 2005). A number of studies in experimental grasslands revealed the significant influence of species richness on the cycling of $\mathrm{N}$ by more exhaustive belowground $\mathrm{N}$ use through complementarity (Tilman et al. 1996; Hooper and Vitousek 1998; Scherer-Lorenzen et al. 2003; Kahmen et al. 2006). However, the relationships of biodiversity and ecosystem functioning are far from being understood in forests. Furthermore, the small-scale experimental results have not yet been linked with replicated largescale observations and generalized across landscapes and different land-use systems (Symstad et al. 2003; Scherer-Lorenzen et al. 2005; Fischer et al. 2010). The latter is necessary to adequately address spatial and functional variability of biogeochemical cycles at different scales and among various management regimes (ranging from coniferous plantations to near-native deciduous forests).

Since the beginning of industrialization, the amount of $\mathrm{N}$ cycling in terrestrial ecosystems has increased and $\mathrm{N}$ from anthropogenic sources has become an important component of the $\mathrm{N}$ cycle in terrestrial ecosystems (Aber et al. 1998; Galloway et al. 2004). Anthropogenic $\mathrm{N}$ is transported and processed in the atmosphere and ultimately deposited mainly as reactive $\mathrm{N}$. Forests receive high $\mathrm{N}$ deposition because of the large canopy surface area and its aerosol and gas scavenging capacity (Horn et al. 1989; Lovett and Lindberg 1993; Rothe et al. 2002). The consequences of $\mathrm{N}$ deposition on the stability and ecosystem services of northern temperate forests have been intensively debated in the context of $\mathrm{N}$ saturation (Aber et al. 1998).
Central European forests are likely under use by humans since several centuries which has resulted in changes of vegetation composition and forest structure (Sala et al. 2000; FAO 2011) and modified plant species richness among forest types (Boch et al. 2013). Especially the introduction and the preferred cultivation of conifers has impacted biogeochemical N cycling compared to native deciduous forests in $\mathrm{Eu}-$ rope through feedbacks on the light and water passing the canopy, changes in litter quality and composition, and nutrient leaching ( $\mathrm{Au}-$ gusto et al. 2002; Rothe et al. 2002; De Schrijver et al. 2007). The cultivation of conifers in areas where deciduous trees would naturally dominate represents an intensified forest management, because coniferous forests evolved from human planting and are usually managed in shorter rotation periods resulting in greater resource exploitation through harvest than in deciduous forests of Germany on the long run (Schmitz et al. 2004). The response of biogeochemical cycles to forest management may vary substantially depending on regional site conditions, resources and ecosystem resilience.

Many findings mainly derived from stable isotope experiments highlight retention, stomatal and microbial uptake, and transformation of dissolved and gaseous $\mathrm{N}$ species (e.g., $\mathrm{NH}_{4}^{+}, \mathrm{NO}_{3}^{-}, \mathrm{NO}_{2}^{-}, \mathrm{NO}_{\mathrm{x}}$, peroxy-acetylnitrate, organic $\mathrm{N}$ ) in forest canopies (e.g., Garten Jr. and Hanson 1990; Sparks et al. 2003; Gaige et al. 2007). However, the physiological capability of using the various atmospheric $\mathrm{N}$ species and thus canopy $\mathrm{N}$ uptake potential depends on plant functional traits like thinner cuticles, more-pronounced leafwettability, higher nitrate reductase activity in deciduous than in coniferous trees. Furthermore, canopy $\mathrm{N}$ retention may also be governed by differences in canopy surface area and seasonality of foliage between coniferous and deciduous trees (Harrison et al. 2000; Augusto et al. 2002) or feedbacks to soil N supply (Rennenberg et al. 1998). Canopy $\mathrm{N}$ uptake of a Norway spruce forest in Germany was estimated to range from $15 \%$ to $42 \%$ of the an- 
nual tree $\mathrm{N}$ demand (Harrison et al. 2000) with the majority taken up as dissolved N (Horn et al. 1989). Therefore, canopy $\mathrm{N}$ retention contributes to plant nutrition and thus potentially increases productivity and carbon sequestration in N-limited forests (Sievering et al. 2007). Moreover, canopy $\mathrm{N}$ retention buffers negative effects of inorganic $\mathrm{N}$ deposition through immobilization, thus, increasing ecosystem stability and supporting ecosystem services like fresh-water supply. Canopy uptake of $\mathrm{NH}_{4}^{+}$and $\mathrm{HNO}_{3}$ by foliage and bark is accompanied by base cation leaching (mainly $\mathrm{K}^{+}$) to maintain a balanced charge in plant cells. Thus, excessive canopy $\mathrm{N}$ uptake may induce base cation leaching from foliage resulting in nutrient imbalances in trees (Horn et al. 1989).

Both, positive and negative biodiversityecosystem functioning relationships were reported from observational forest studies (Vila et al. 2003; 2007; Morin et al. 2011; Paquette and Messier 2011), but these studies focused solely on the relationship between mature tree diversity and productivity. Hence, the existence of a complementarity effect in forests is still under debate because it can only be proven using strict experimental sampling designs to overcome the 'sampling-effect' (Wardle 1999). Such a degree of experimental control of driving factors can hardly be reached in structurally complex ecosystems like forests because the understorey species composition in forests is not fully independent of the regional species pool, the dominant tree species, and forest management, respectively (Boch et al. 2013). Nevertheless, the assumption that species-rich plant assemblages improve N-use efficiency through complementary use of $\mathrm{N}$ should also hold true for forests (Scherer-Lorenzen et al. 2005). To our knowledge, a biodiversity effect has never been evaluated with respect to aboveground nutrient use in forests via plant surfaces. Several comparative studies addressed the influence of single and admixed tree species on nutrientuse efficiency in terms of $\mathrm{N}$ leaching (Nordin 1991; Kelty 2006; Berger et al. 2009) but, to our knowledge, no study investigated the functional role of vascular plant diversity on canopy
$\mathrm{N}$ retention including the forest understorey although the diversity of woody canopy-forming understorey plants usually exceeds tree species diversity in managed Central European forests and the understorey vegetation competes for $\mathrm{N}$ resources with overstorey trees (Gebauer et al. 2000).

Our objective was to quantify the canopy budget of $\mathrm{N}$ in a range of central European forests to determine drivers of this budget. We hypothesized that canopy $\mathrm{N}$ budgets are driven by (1) the type of forest system determined by tree species and management intensity (reflected by the basal area) and (2) richness and diversity of trees and shrubs forming the forest canopy.

\section{Materials and methods}

\subsection{Study site}

This study was conducted as part of the "Biodiversity Exploratories" project (www.biodiversity-exploratories.de) in three regions in Germany, Schorfheide-Chorin, Hainich-Dün, and Schwäbische Alb, where the assessments are conducted in established and actively managed forests (for details see Fischer et al. 2010). The three research regions differ in climate, geological setting and prevalent soils that are representative for large parts of Central Europe (Table 1). In each region, we investigated 9 forest plots $(100 \mathrm{~m} \mathrm{x}$ $100 \mathrm{~m}$ ) comprising age-class forests (i.e. forests consisting of one or more even-aged development stages which are harvested at 80-120 year intervals by clear cut or shelterwood logging) dominated by European beech (Fagus sylvatica L.), Norway spruce (Picea abies (L.) H. Karst.), and Scots pine (Pinus sylvestris L.), respectively, and extensively managed forests (mature forests protected for at least 60 years) dominated by European beech (Fischer et al. 2010). The dominating tree species of the studied forests (Table 3) are representative for large parts of the respective region (Fischer et al. 2010). 
Table 1: Main environmental properties of the three study regions partially taken from Fischer et al. (2010). Soil classification according to IUSS Working group WRB (2006).

\begin{tabular}{|c|c|c|c|}
\hline & Schorfheide-Chorin & Hainich-Dün & Schwäbische Alb \\
\hline Location & $\begin{array}{c}\text { NE Germany } \\
\left(53^{\circ} 2^{\prime} \mathrm{N}, 13^{\circ} 51^{\prime} \mathrm{E}\right)\end{array}$ & $\begin{array}{c}\text { Central Germany } \\
\left(51^{\circ} 10^{\prime} \mathrm{N}, 10^{\circ} 23^{\prime} \mathrm{E}\right)\end{array}$ & $\begin{array}{c}\text { SW Germany } \\
\left(48^{\circ} 24^{\prime} \mathrm{N}, 9^{\circ} 24^{\prime} \mathrm{E}\right)\end{array}$ \\
\hline Altitude & 3-140 m a.s.l. & $285-550 \mathrm{~m}$ a.s.l. & $460-860 \mathrm{~m}$ a.s.l. \\
\hline Population density & $23 \mathrm{~km}^{-2}$ & $116 \mathrm{~km}^{-2}$ & $258 \mathrm{~km}^{-2}$ \\
\hline Mean annual temperature & $8-8.5^{\circ} \mathrm{C}$ & $6.5-8^{\circ} \mathrm{C}$ & $6-7^{\circ} \mathrm{C}$ \\
\hline Mean annual precipitation & $500-600 \mathrm{~mm}$ & $500-800 \mathrm{~mm}$ & $700-1000 \mathrm{~mm}$ \\
\hline Bedrock & $\begin{array}{l}\text { Quarternary quartzitic sand } \\
\text { (glacial till) }\end{array}$ & $\begin{array}{l}\text { lacustrine limestone / } \\
\text { Triassic sandstone / loess }\end{array}$ & Jurassic limestone \\
\hline Soils & $\begin{array}{c}\text { Cambisols } \\
\text { Albeluvisols }\end{array}$ & $\begin{array}{c}\text { Luvisols } \\
\text { Stagnosols }\end{array}$ & $\begin{array}{l}\text { Leptosols } \\
\text { Cambisols }\end{array}$ \\
\hline Common tree species & $\begin{array}{l}\text { Fagus sylvatica } \mathrm{L} . \\
\text { Pinus sylvestris } \mathrm{L} . \\
\quad \text { Quercus spp. }\end{array}$ & $\begin{array}{l}\text { Fagus sylvatica L. } \\
\text { Picea abies (L.) H. Karst. } \\
\text { Carpinus betulus L. }\end{array}$ & $\begin{array}{c}\text { Fagus sylvatica L. } \\
\text { Picea abies (L.) H. Karst. }\end{array}$ \\
\hline
\end{tabular}

\subsection{Sampling and chemical analysis}

Fluxes of $\mathrm{Cl}^{-}, \mathrm{K}, \mathrm{Na}$, total dissolved $\mathrm{N}(\mathrm{TN})$, $\mathrm{NO}_{3}^{-}, \mathrm{NH}_{4}^{+}$, dissolved organic $\mathrm{N}(\mathrm{DON})$, and total dissolved phosphorous with bulk deposition, throughfall, stemflow, and litter leachate were determined at intervals of 14 days for the growing season of 2010 (30 March to 9 November 2010 for Schwäbische Alb and Hainich-Dün, respectively, 14 April to 9 November 2010 for Schorfheide-Chorin). During some sampling campaigns, forest plots in Hainich-Dün $(n=1)$ and Schorfheide-Chorin $(\mathrm{n}=8)$ were inaccessible because of hunting or harvest, therefore some samples of throughfall and stemflow refer to sampling periods of 28 days.

Rainfall was sampled at grassland sites distributed throughout the study regions (9 to 11 sampling sites) with 5 collectors per site placed at $1.8 \mathrm{~m}$ height. Obviously contaminated samples of rainfall were discarded in the field (Schwäbische Alb: 27\%, Hainich-Dün: 17\%, Schorfheide-Chorin: 24\%). Throughfall was sampled with 20 collectors per forest site in a subplot $(20 \mathrm{~m} \times 20 \mathrm{~m})$ at $0.3 \mathrm{~m}$ above the soil surface to include the influence of overstoreys and understoreys of the canopy. Collectors for rainfall and throughfall consisted of 2-L polyethylene bottles equipped with a polyethylene funnel (diameter $=0.12 \mathrm{~m}$ ). To prevent photochemical reactions, the sampling bottle was wrapped with aluminum foil. Funnels were equipped with a polyester mesh $(1.6 \mathrm{~mm}$ mesh width) and a table-tennis ball to prevent contamination with coarse particulate matter and to minimize evaporation, respectively. Collectors for rainfall and throughfall were continuously open and therefore collected bulk deposition. However, the aerosol capturing capacity of collectors is negligible compared to that of forest canopies. Stemflow was collected from 3 trees per site using bisected polyurethane hoses (diameter $=0.04 \mathrm{~m}$ ) as a collar fixed to the bark with a polyurethane-based sealing, and connected to a polyethylene tubing as drain outlet to a polyethylene or polypropylene trough (15 to $220 \mathrm{~L}$ ). Litter leachate was sampled with 3 zero-tension lysimeters (diameter $=0.2 \mathrm{~m}$, polyvinyl chloride) per site which were installed horizontally below the organic layer and collected the sample in polyethylene bottles stored belowground.

Bulk precipitation for each forest plot was assessed using RADOLAN data provided by German Weather Service (DWD, Offenbach, Germany) gathered from radio detection and ranging methods that have a temporal, spatial, and intensity resolution of $1 \mathrm{~h}, 1 \mathrm{~km}^{2}$, and $0.1 \mathrm{~mm}$, respectively, and were calibrated with biweekly volumetric precipitation measurements at ground level. During each sampling campaign, the volume of water intercepted by each collector was measured and a volume-weighted aliquot of each sample type 
Table 2: Analytical devices used to determine concentrations of total dissolved nitrogen (TN), $\mathrm{NH}_{4}^{+}-\mathrm{N}$, $\mathrm{NO}_{3}^{-}-\mathrm{N}, \mathrm{Cl}^{-}, \mathrm{K}, \mathrm{Na}$, and total dissolved phosphorous (TDP) in samples of rainfall, throughfall, stemflow, and litter leachate from Schwäbische Alb, Hainich-Dün, and Schorfheide-Chorin, respectively. Manufacturers and addresses are given when first mentioned.

\begin{tabular}{|c|c|c|c|}
\hline Parameter & source region of sample & Analytical device & Device specifications \\
\hline \multirow[t]{4}{*}{$\mathrm{TN}$} & Schorfheide-Chorin & TOC Analyzer & VCPH, Shimadzu, Düsseldorf, Germany \\
\hline & Hainich-Dün & TOC Analyzer & VCPN, Shimadzu \\
\hline & Schwäbische Alb & TOC Analyzer & VarioTOC cube, Elementar \\
\hline & & & Analysensysteme GmbH, Hanau, Germany \\
\hline $\mathrm{NH}_{4}^{+}$ & all & $\begin{array}{l}\text { Continuous Flow Analyzer } \\
\text { (photometer) }\end{array}$ & $\begin{array}{l}\text { AutoAnalyzer 3, Seal Analytical GmbH, } \\
\text { Norderstedt, Germany }\end{array}$ \\
\hline $\mathrm{NO}_{3}^{-}$ & all & $\begin{array}{l}\text { Continuous Flow Analyzer } \\
\text { (photometer) }\end{array}$ & AutoAnalyzer 3 \\
\hline $\mathrm{Cl}^{-}$ & all & $\begin{array}{l}\text { Continuous Flow Analyzer } \\
\text { (ion-selective electrode) }\end{array}$ & $\begin{array}{l}\text { AutoAnalyzer } 3 \text {; Orion } 9417 \mathrm{BN} \text {, } \\
\text { Thermo Scientific, Nijkerk, The Netherlands }\end{array}$ \\
\hline \multirow[t]{3}{*}{$\mathrm{K}, \mathrm{Na}$} & Schorfheide-Chorin & Atomic absorption spectrometer & $\begin{array}{l}\text { AAnalyst 300, PerkinElmer Inc., } \\
\text { Norwalk, MA, USA }\end{array}$ \\
\hline & Hainich-Dün & $\begin{array}{l}\text { Inductively-coupled plasma } \\
\text { optical emission spectrometer }\end{array}$ & Liberty 150, Varian, Mulgrave, Australia \\
\hline & Schwäbische-Alb & Atomic absorption spectrometer & $\begin{array}{l}\text { ZEEnit 700p, Jena Analytik GmbH, } \\
\text { Jena, Germany }\end{array}$ \\
\hline TDP & all & $\begin{array}{l}\text { Continuous Flow Analyzer } \\
\text { (photometer) }\end{array}$ & AutoAnalyzer 3 \\
\hline
\end{tabular}

per plot was created in the field that was filtered through pre-rinsed (at least $0.05 \mathrm{~L}$ distilled water and $0.05 \mathrm{~L}$ sample) folded paper filters (low N concentration, 5-8 $\mu \mathrm{m}, 292$, Munktell \& Filtrak GmbH, Bärenstein, Germany, and Sartorius AG, Göttingen, Germany) and were stored at $-18^{\circ} \mathrm{C}$ until chemical analysis. Analytical devices used to determine concentrations of $\mathrm{TN}, \mathrm{NH}_{4}^{+}-\mathrm{N}, \mathrm{NO}_{3}^{-}-\mathrm{N}, \mathrm{Cl}^{-}, \mathrm{K}, \mathrm{Na}$ and total dissolved phosphorous are summarized in Table 2. DON concentrations were calculated as TN minus $\mathrm{NO}_{3}^{-}-\mathrm{N}$ minus $\mathrm{NH}_{4}^{+}-\mathrm{N}$. Concentrations of $\mathrm{TN}$ were adjusted to equal $\mathrm{NO}_{3}^{-} \mathrm{N}$ plus $\mathrm{NH}_{4}^{+}-\mathrm{N}$ if calculated DON concentrations were negative (Schwäbische Alb: 6\% of samples; Hainich-Dün: 12\%; Schorfheide-Chorin: $9 \%)$.

\subsection{Forest and vegetation properties}

In each plot, diameter at breast height of all trees was measured between 2008 and 2012 . Basal area of trees was calculated and summed for each plot to give total basal area. Richness of woody plant species was determined in each forest stand in a $20 \mathrm{~m} \times 20 \mathrm{~m}$ subplot for shrubs
( $<5 \mathrm{~m}$ height) and trees ( $>5 \mathrm{~m}$ height) in summer 2010. For each plot, the Shannon index of woody plant species was calculated according to the equation

$$
\text { Shannon index }=-\sum_{i=1}^{S} p_{i} * \ln \left(p_{i}\right),
$$

where $\mathrm{S}$ denotes the total number of tree and shrub species present, i identifies an individual species, and $\mathrm{p}_{i}$ is the species-specific cover value of species i.

Management intensity was approximated by forest type and total basal area. The forest type component is factorial and distinguishes between coniferous (intensively managed) and deciduous forests (extensively managed). The basal area component reflects shortterm human disturbances through thinning, planting and harvest (i.e. management reduces total basal area) but also natural disturbances. 


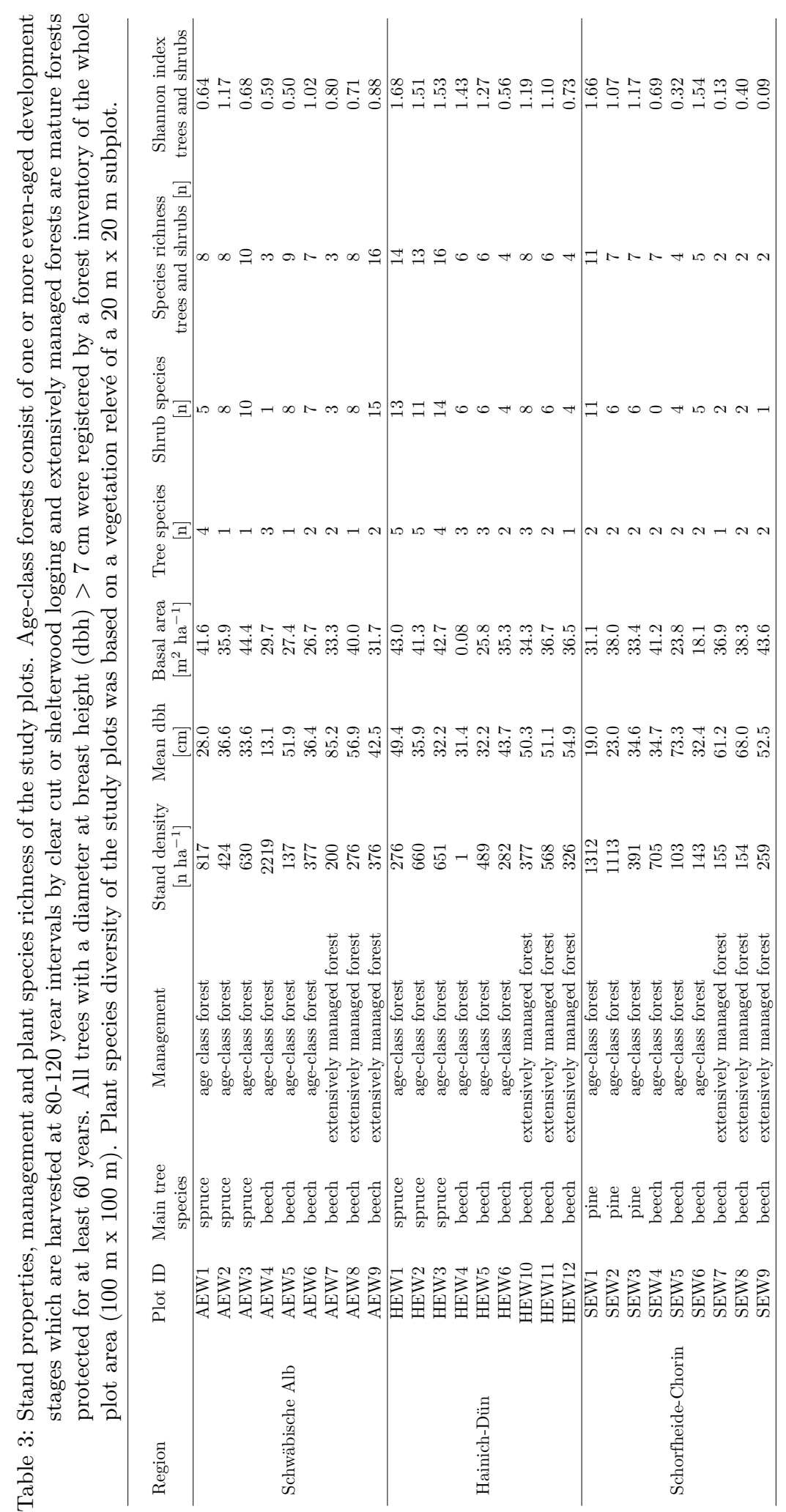




\subsection{Calculations and statistics}

\subsubsection{Calculations}

Bulk deposition for each forest plot was calculated by multiplying site-specific bulk precipitation (RADOLAN data) and volume-weighted element concentration of rainfall for the growing season. Element concentrations in rainfall that referred to a sampling period $>14$ days were excluded a priori from the analysis (Schwäbische Alb: 0\%, Hainich-Dün: 2\%, Schorfheide-Chorin: 17\%). Because of frequent contamination of rainfall samples, we excluded outliers that were outside of the $1.5 \times$ interquartile range for (1) total dissolved phosphorous deposition (bird droppings), (2) electrical conductivity and (3) TN concentration (both fertilizer input), (4) of $0.5<\mathrm{Na}$ to $\mathrm{Cl}$ ratio $<1.5$ (plausibility), and $(5) \mathrm{Cl}^{-}$concentration (human contamination because of sample handling). Outlier identification was performed sequentially and for each exploratory separately and steps (2),(3), and (5) were based on single sampling events because of apparent seasonal patterns. In total, $\mathrm{n}=86, \mathrm{n}=94$, and $\mathrm{n}=65$ samples of rainfall from Schwäbische Alb, Hainich-Dün, and Schorfheide-Chorin, respectively, were used for the quantification of bulk deposition.

Throughfall water flux was calculated as mean of all samplers per plot. At one plot in HainichDün (HEW4), sampling started 4 weeks later and ended 2 weeks earlier than at the other plots in Hainich-Dün and the throughfall water flux for these sampling periods was substituted using linear regression of precipitation and throughfall $\left(\mathrm{r}^{2}=0.82\right)$. Throughfall collectors at one plot in Schorfheide-Chorin (SEW2) had to be removed between 8 June 2010 and 22 June 2010, however, precipitation was $\sim 2 \mathrm{~mm}$ for this period and we therefore set throughfall water flux to 0. Stemflow water flux was calculated by scaling up the measured stemflow volume per basal area of the sampled trees to total basal area of the respective forest. We did not substitute missing stemflow water fluxes (Schwäbische Alb: 2\%; Hainich-Dün:
21\%; Schorfheide-Chorin: 1\%) because stemflow can poorly be inferred from rainfall volume and we therefore underestimate stemflow fluxes at some sites.

Element fluxes with throughfall and stemflow were calculated for each plot by multiplying volume and element concentration for each sampling campaign which were then summed up over the growing season. No samples of throughfall, stemflow, and litter leachate were removed from the dataset, except $\mathrm{Cl}^{-}$concentration in throughfall of one plot in HainichDün (HEW4) between September 14th and 28th because of obvious contamination. In contrast to rainfall, throughfall samples that refer to a sampling period of 28 days were not excluded from the analysis because the ratio of $\mathrm{NH}_{4}^{+}-\mathrm{N}$ to $\mathrm{NO}_{3}^{-}-\mathrm{N}$ did not differ between throughfall samples with sampling periods of 14 days and 28 days ( $P=0.385$, t-test) indicating negligible $\mathrm{N}$ transformations in the samples. Missing element concentrations for throughfall and stemflow because of sample exhaustion by chemical analysis or plot inaccessibility were substituted by volume-weighted mean concentrations. We used the volume-weighted mean of $\mathrm{NH}_{4}^{+}-\mathrm{N}$ plus $\mathrm{NO}_{3}^{-}-\mathrm{N}\left(\mathrm{N}_{\text {min }}\right)$ concentration in litter leachate to describe $\mathrm{N}$ availability in soil.

Element fluxes with throughfall plus stemflow were considered as below canopy flux. Total deposition was calculated as bulk deposition plus dry deposition. Since dry deposition cannot be measured directly, total deposition was estimated according to the canopy budget model of Ulrich (1983) using $\mathrm{Cl}^{-}$as a tracer for dry deposition. The model is based on the assumption that $\mathrm{Cl}^{-}$is inert during the canopy passage, hence, $\mathrm{Cl}^{-}$enrichment from bulk deposition to below canopy flux results solely from dry deposition. We did not determine gaseous dry deposition and therefore underestimate total deposition to the studied forests. Finally, the canopy budget was calculated as below canopy flux $m i$ nus total deposition. A negative budget indicates uptake or retention of $\mathrm{N}$ in the canopy. For unknown reasons, total deposition exceeded below canopy flux of $\mathrm{Cl}^{-}$at Schorfheide-Chorin 
from 15 September 2010 until 9 November 2010 and calculation of dry deposition was therefore based on $\mathrm{Cl}^{-}$canopy budgets of the preceding period (14 April 2010 to 14 September 2010).

\subsubsection{Statistics}

Data were analyzed using the software environment R (R Development Core Team 2011). Differences between paired samples were tested with the Wilcoxon matched-pairs test. Twogroup comparisons were performed with a ttest. Multiple group comparisons were performed with a one-way ANOVA (F-Test) followed by Tukey's honest significant differences post-hoc test with Bonferroni correction. Nitrogen canopy budgets were analyzed with sequential ANCOVA (Type I, sum of squares). Model development was based on the principles of marginality, backward selection and singleterm deletion of a full model containing region, forest type (i.e. coniferous or deciduous), basal area, $\mathrm{N}_{\text {min }}$ in litter leachate, Shannon index, and all two-term interactions as explanatory variables. Preliminary correlation analysis of interactions of two continuous covariates identified predominance of at least one main effect (i.e. $\mathrm{r}_{\text {Pearson }}>0.6$ ), thus, these interactions were not included in the initial model. Main effects could only be removed from the model if they were not part of an interaction term. Model development was performed until further term deletion decreased model quality significantly (F-test). One plot in Hainich-Dün (HEW4) was identified as a highly influential observation on model results by a Cook's distance value of $>1$ because of the low number of mature trees on this plot (Table 3) and thus was excluded from the model development. A second plot in Hainich-Dün (HEW10) was identified as an outlier with respect to the canopy budget of TN $\left(-8.2 \mathrm{~kg} \mathrm{ha}^{-1}\right)$ on a within region basis violating the assumption of homogeneity and thus was excluded from the linear model. For visualization of the biodiversity effect we calculated residuals of a linear model containing only main effects of region, forest type and stand density. For all models, Gaussian distribution of residuals and homogeneity of variances were inspected visually and verified with the Anderson-Darling and the Fligner-Killeen tests, respectively.

\section{Results}

\subsection{Total $\mathrm{N}$ fluxes and differences among regions}

Bulk deposition of TN was greater in Schorfheide-Chorin (11.8土 standard deviation (SD) $1.7 \mathrm{~kg} \mathrm{ha}{ }^{-1}$ ) than in Hainich-Dün $\left(10.1 \pm 0.8 \mathrm{~kg} \mathrm{ha}^{-1}, P=0.011\right)$ but similar to Schwäbische Alb $11.1 \pm 0.6 \mathrm{~kg} \mathrm{ha}{ }^{-1}$. Total deposition of TN was similar in all three regions (Table 4, Fig. 1). Below canopy flux of TN was lower than total deposition of $\mathrm{TN}(P<0.001$; Fig. 1). The canopy budget of $\mathrm{TN}$ covered a wide range from $-15.6 \mathrm{~kg} \mathrm{ha}^{-1}$ to $+1.5 \mathrm{~kg}$ $\mathrm{ha}^{-1}$ (Fig. 1) and differed among regions (Table 5). On average, $29 \%, 16 \%$, and $51 \%$ of total deposition of $\mathrm{TN}$ was retained in the canopy in Schwäbische Alb, Hainich-Dün, and Schorfheide-Chorin, respectively. The canopy budget of TN was negatively correlated with total deposition of TN (Fig. 2). Comparisons of dry deposition, total deposition and below canopy fluxes of TN among regions and of fractional contributions of $\mathrm{N}$ species in total deposition and below canopy fluxes are summarized in Table 4 and Fig. 1.

The charge-equivalent retention of $\mathrm{NO}_{3}^{-}$was $30.2 \pm 12.4 \mathrm{mmol}_{c} \mathrm{ha}^{-1}$ in Schorfheide-Chorin, whereas $\mathrm{NH}_{4}^{+}$retention $\left(26.2 \pm 11.2 \mathrm{mmol}_{c}\right.$ $\mathrm{ha}^{-1}$ ) equaled leaching of $\mathrm{K}^{+}$from forest canopies $\left(28.1 \pm 11.3 \mathrm{mmol}_{c} \mathrm{ha}^{-1}\right)$. In Schwäbische Alb, $\mathrm{K}^{+}$leaching from canopies $\left(43.2 \pm 14.1 \mathrm{mmol}_{c} \mathrm{ha}^{-1}\right)$ exceeded $\mathrm{NH}_{4}^{+}$retention $\left(7.4 \pm 6.5 \mathrm{mmol}_{c} \mathrm{ha}^{-1}\right)$ but the gap was compensated by $\mathrm{NO}_{3}^{-}$retention $(34.0 \pm 17.6$ $\left.\operatorname{mmol}_{c} \mathrm{ha}^{-1}\right)$. $\mathrm{NH}_{4}^{+}$retention $\left(16.3 \pm 6.5 \mathrm{mmol}_{c}\right.$ $\left.\mathrm{ha}^{-1}\right)$ was smaller than $\mathrm{K}^{+}$leaching $(50.8 \pm 19.2$ $\mathrm{mmol}_{c} \mathrm{ha}^{-1}$ ) from canopies in Hainich-Dün where $\mathrm{NO}_{3}^{-}-\mathrm{N}$ retention $\left(5.3 \pm 14.7 \mathrm{mmol}_{c} \mathrm{ha}^{-1}\right)$ was negligible. 
Table 4: Comparison of fluxes of total dissolved nitrogen (TN) among regions and forest types studied, respectively, and of canopy budgets of dissolved organic nitrogen (DON), $\mathrm{NH}_{4}^{+}-\mathrm{N}$, and $\mathrm{NO}_{3}^{-}$ $\mathrm{N}$ within regions if not presented in the results section. Logical operators indicate significant differences at the $P<0.05$ level. Quantitative information is shown in Fig. 1.

\begin{tabular}{|c|c|c|}
\hline Comparison & Flux & Result \\
\hline \multirow{4}{*}{$\begin{array}{l}\text { Differences among } \\
\text { regions }\end{array}$} & Bulk deposition of TN & Schwäbische Alb $\approx$ Hainich-Dün $<$ Schorfheide-Chorin \\
\hline & Dry deposition of TN & Schwäbische $\mathrm{Alb} \approx$ Hainich-Dün $\approx$ Schorfheide-Chorin \\
\hline & Total deposition of TN & Schwäbische $\mathrm{Alb} \approx$ Hainich-Dün $\approx$ Schorfheide-Chorin \\
\hline & Below canopy flux of TN & Schwäbische $\mathrm{Alb} \approx$ Hainich-Dün $>$ Schorfheide-Chorin \\
\hline \multirow{5}{*}{$\begin{array}{l}\text { Differences among } \\
\mathrm{N} \text { species }\end{array}$} & Total deposition & Schwäbische Alb: DON $<\mathrm{NH}_{4}^{+}-\mathrm{N}<\mathrm{NO}_{3}^{-}-\mathrm{N}$ \\
\hline & & Hainich-Dün: DON $<\mathrm{NH}_{4}^{+}-\mathrm{N}<\mathrm{NO}_{3}^{-}-\mathrm{N}$ \\
\hline & & Schorfheide-Chorin: $\mathrm{DON}<\mathrm{NH}_{4}^{+}-\mathrm{N} \approx \mathrm{NO}_{3}^{-}-\mathrm{N}$ \\
\hline & Canopy budget & $\begin{array}{l}\text { Schwäbische Alb: DON }>0>\mathrm{NH}_{4}^{+}-\mathrm{N}>\mathrm{NO}_{3}^{-}-\mathrm{N} \\
\text { Hainich-Dün: DON }>\mathrm{NO}_{3}^{-}-\mathrm{N} \approx 0>\mathrm{NH}_{4}^{+}-\mathrm{N} ;\end{array}$ \\
\hline & & Schorfheide-Chorin: $0>\mathrm{DON}>\mathrm{NH}_{4}^{+}-\mathrm{N} \approx \mathrm{NO}_{3}^{-}-\mathrm{N}$ \\
\hline \multirow{3}{*}{$\begin{array}{l}\text { Differences among } \\
\text { forest types }\end{array}$} & Below canopy flux of TN & Schwäbische Alb: coniferous $\approx$ deciduous; \\
\hline & & Hainich-Dün: coniferous > deciduous; \\
\hline & & Schorfheide-Chorin: coniferous $\approx$ deciduous \\
\hline
\end{tabular}

\subsection{Effects of forest type and stand density}

Because of the greater dry deposition, total deposition of $\mathrm{TN}$ was greater in coniferous than in deciduous forests of Schwäbische Alb and Hainich-Dün $(P<0.036)$, respectively (Fig. 1). Canopy retention of TN was greater in coniferous than in deciduous forests (Table 5). However, the interaction between forest type and region was only significant in Schwäbische Alb and Schorfheide-Chorin $(P=0.010)$. Below canopy fluxes of TN differed between coniferous and deciduous forests exclusively in HainichDün (Table 4). Stand density was similar in all three regions and greater in coniferous than in deciduous forests $(P=0.017)$. The canopy budget of TN increased with the stand density in coniferous forest while the opposite was true for deciduous forests rendering the overall effect of stand density on all studied forests negligible (Table 5). Furthermore, differences in canopy $\mathrm{N}$ budget among coniferous age-class forests, deciduous age-class forests, and extensively managed forests only reflected differences between the forest types.

\subsection{Influence of plant diversity}

The diversity of trees and shrubs differed marginally among the three regions $(P=0.057)$ and tended to be lowest in Schorfheide-Chorin and highest in Hainich-Dün (Table 3). The Shannon index was higher in coniferous than in deciduous forests $(P=0.012)$. The Shannon index explained $14 \%$ of the variance in the canopy budget of TN (Table 5) and tended to be positively correlated with the residual canopy budget of TN after accounting for region, forest type and stand density (i.e. supporting canopy $\mathrm{N}$ retention; Fig. 3). The effect of plant diversity varied significantly among regions and forest types, respectively (interaction terms in Table 5).

\section{Discussion}

\subsection{Effects of region and forest management intensity on canopy $\mathrm{N}$ retention}

Canopy budgets of TN were almost entirely negative indicating widespread net $\mathrm{N}$ retention (Fig. 1). Canopy $\mathrm{N}$ retention occurs frequently in temperate forests deficient in $\mathrm{N}$ and forest 

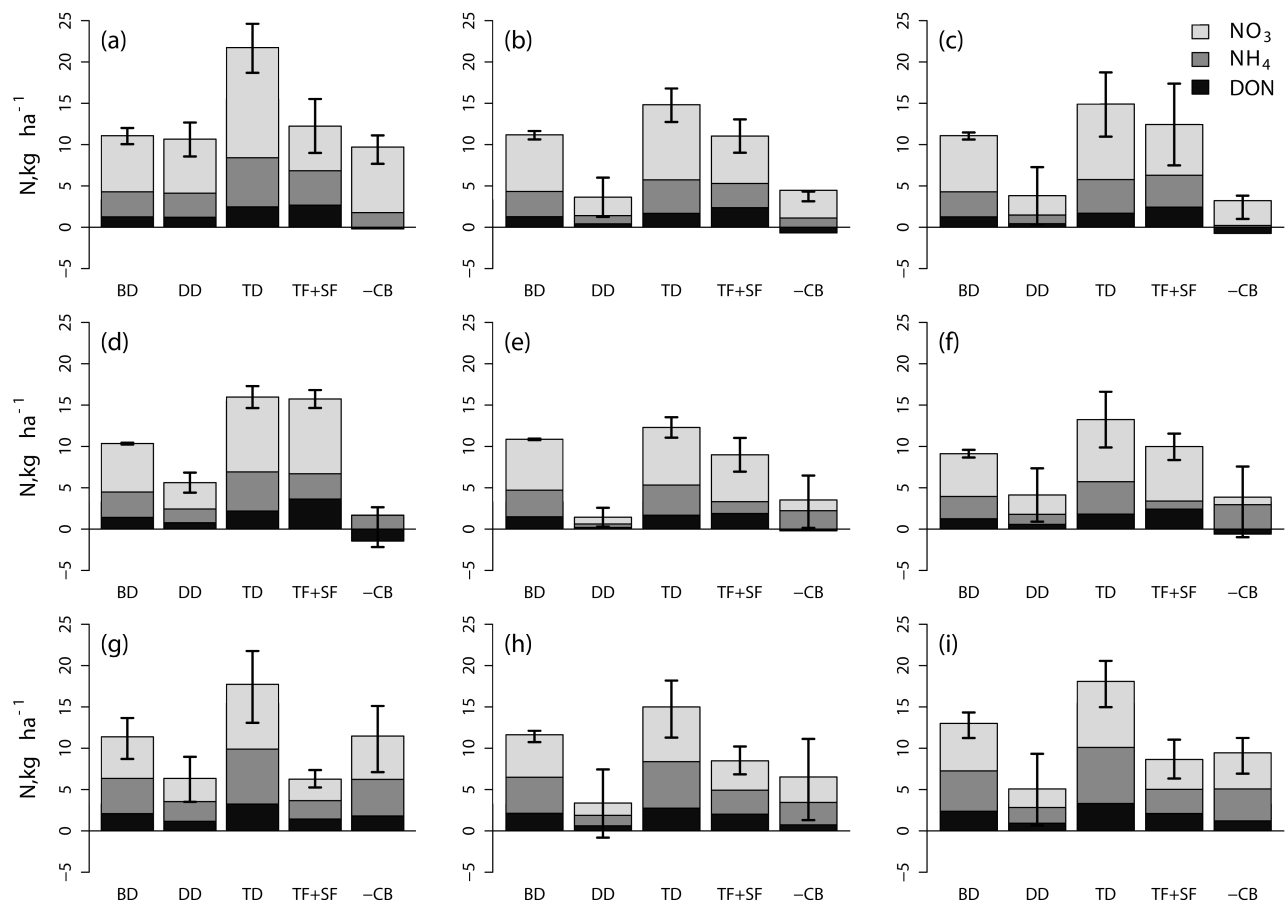

Fig. 1: Bulk deposition (BD), dry deposition (DD), total deposition (TD), throughfall+stemflow flux $(\mathrm{TF}+\mathrm{SF})$, and the canopy budget (multiplied by -1 for better visualization; -CB) of total dissolved $\mathrm{N}(\mathrm{TN})$ separated by $\mathrm{NO}_{3}^{-}-\mathrm{N}, \mathrm{NH}_{4}^{+}-\mathrm{N}$ and $\mathrm{DON}$ in spruce age-class forests (a, d), pine age-class forests $(\mathrm{g})$, beech age-class forests $(\mathrm{b}, \mathrm{e}, \mathrm{h})$, and extensively managed beech forests (c, f, i) in Schwäbische Alb (a, b, c), Hainich-Dün (d, e, f), and Schorfheide-Chorin (g, h, i), respectively, for the growing season 2010. Error bars show mean \pm standard deviation of $T N$ fluxes $(S D, n=3)$. Note that the offset of the error bars of -CB of TN is caused by the the release of DON from the canopy.

canopies in North America receiving low to intermediate $\mathrm{N}$ deposition usually retain 10 to $90 \%$ (mean of $40 \%$ ) of annual wet $\mathrm{N}$ deposition (Lovett and Lindberg 1993). Foliar N uptake was estimated to provide up to $50 \%$ of plant N demand (Sievering et al. 2007) and thus may counteract $\mathrm{N}$ limitation (Sparks et al. 2003). Similar to our study, canopy N retention in North America increased with $\mathrm{N}$ deposition (Lovett and Lindberg 1993; Fig. 2), Thus, regional differences in the canopy budget of TN in our study are likely related to the magnitude of $\mathrm{N}$ deposition and the forest $\mathrm{N}$ status. However, the proxy we used for $\mathrm{N}$ availability to roots (i.e. $\mathrm{N}_{\text {min }}$ in litter leachate) did not influence the canopy budget of TN. Given the sandy soil texture in Schorfheide-
Chorin and the shallowness of soils in Schwäbische Alb, respectively, $\mathrm{N}$ availability to roots may also be limited by water-shortage resulting from the low water holding capacity of the soils in Schorfheide-Chorin or small soil N stocks in Schwäbische Alb, rendering canopy uptake of deposited N more important in SchorfheideChorin and Schwäbische Alb than in HainichDün. Accordingly, canopy N uptake in HainichDün might have been limited because local soil properties (e.g., high fertility, high water and nutrient storage capacity of the soils) render $\mathrm{N}$ nutrition by root uptake more efficient resulting in $\mathrm{N}$ accumulation within the plant and decreased foliar $\mathrm{N}$ uptake (Rennenberg et al. 1998).

Deposited $\mathrm{N}$ is prone to chemical, biological, 
Table 5: Analysis of (co-)variance (sequential, type I sum of squares) table with the canopy budget of total dissolved $\mathrm{N}$ as response variable $(\mathrm{n}=25)$. Asterisks highlight significant variances.

\begin{tabular}{lrrrrrr}
\hline & Df & Sum Sq & Mean Sq & F value & P $(>\mathrm{F})$ & \\
\hline Region & 2 & 254.4 & 127.2 & 65.4 & $<0.001$ & $* * *$ \\
Forest type & 1 & 56.4 & 56.4 & 29.0 & $<0.001$ & $* * *$ \\
Basal area & 1 & 6.15 & 6.15 & 3.16 & 0.099 & \\
Shannon index & 1 & 70.3 & 70.3 & 36.1 & $<0.001$ & $* * *$ \\
Region $\times$ forest type & 2 & 19.2 & 9.58 & 4.92 & 0.026 & $*$ \\
Region $\times$ Shannon index & 2 & 26.6 & 13.3 & 6.83 & 0.009 & $* *$ \\
Forest type $\times$ basal area & 1 & 17.8 & 17.8 & 9.13 & 0.010 & $*$ \\
Forest type $\times$ Shannon index & 1 & 11.9 & 11.9 & 6.14 & 0.028 & $*$ \\
Residuals & 13 & 25.3 & 1.95 & & &
\end{tabular}

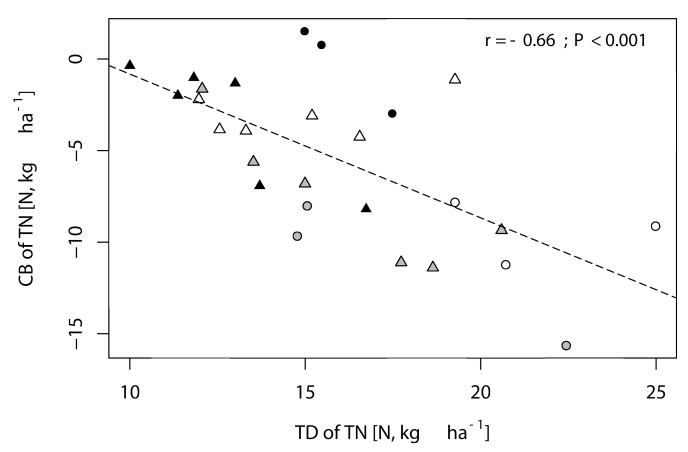

Fig. 2: Relationship of total deposition and canopy budget of total dissolved $\mathrm{N}(\mathrm{TN})$ of the growing season 2010. Open, black, and gray symbols refer to plots from Schwäbische Alb, Hainich-Dün, and Schorfheide-Chorin, respectively. Circles and triangles refer to coniferous and deciduous forests, respectively. The dashed line is the regression line.

and physical interactions with canopy surfaces and organisms. Major sinks for deposited $\mathrm{N}$ in the canopy are foliar uptake by plants through stomatal penetration and cuticular diffusion (e.g. Eilers et al. 1992; Peuke et al. 1998; Lockwood et al. 2008) that is usually accompanied by ion exchange and leaching, assimilation by epiphytes and microbes (Papen et al. 2002; Gaige et al. 2007; Schwarz et al. 2011), and ion adsorption to canopy surfaces (Dail et al. 2009; Adriaenssens et al. 2012). The canopy can also be a source of dissolved $\mathrm{N}$ through dissolution of dry deposited particles and gases and leaching from organic tissues (e.g., DON, Fig. 1), respectively. All of these sinks and sources occur simultaneously and should be related to species-specific canopy surface properties or functional traits. The good agreement of $\mathrm{K}^{+}$leaching and $\mathrm{NH}_{4}^{+}$retention in $\mathrm{mmol}_{c}$ $\mathrm{m}^{-2}$ in Schorfheide-Chorin suggested that foliar uptake accompanied by ion exchange is a potentially important sink for $\mathrm{N}$ in the canopy. The fact that $\mathrm{K}^{+}$leaching in Schwäbische Alb and Hainich-Dün was greater than the $\mathrm{NH}_{4}^{+}$ retention in $\mathrm{mmol}_{c} \mathrm{~m}^{-2}$ indicates that either we underestimated $\mathrm{NH}_{4}^{+}$retention because we did not consider gaseous $\mathrm{NH}_{3}$ deposition or that there were additional acid inputs causing canopy $\mathrm{H}^{+}$buffering by $\mathrm{K}^{+}$leaching. Part of the acid inputs might originate from gaseous $\mathrm{HNO}_{3}$ deposition. While $\mathrm{NO}_{3}^{-}$may be taken up by the plant in a charge-neutral way by release of anions like $\mathrm{OH}^{-}$, the $\mathrm{H}^{+}$is buffered by $\mathrm{K}^{+}$leaching. Consequently, $\mathrm{K}^{+}$leaching in $\mathrm{mmol}_{c} \mathrm{~m}^{-2}$ matched the uptake of $\mathrm{NH}_{4}^{+}$and $\mathrm{NO}_{3}^{-}$in Schwäbische Alb.

Generally, canopy surface area and roughness are greater in coniferous than in deciduous forests (Augusto et al. 2002). Canopy properties of spruce forest increased dry deposition of TN (Fig. 1) and provided a larger reactive surface for adsorption and assimilation relative to deciduous forests because of permanent foliage (Harrison et al. 2000) as reflected by the significant effect of forest type on the canopy budget of TN (Table 5). The effect of the forest type differed among regions (Table 5). 
The structural differences between coniferous and deciduous forests are unlikely to vary substantially among regions. More probably, coniferous and deciduous forests adapt their N acquisition strategies differently in relation to the regional $\mathrm{N}$ status. This also suggests that biotic retention (e.g., assimilation) is more important than abiotic retention (e.g., adsorption).

In line with other studies, coniferous forests retained atmospheric $\mathrm{N}$ more efficiently than deciduous forests in Schwäbische Alb and Schorfheide-Chorin (Rothe et al. 2002; De Schrijver et al. 2007; Table 5). This difference may have been marginalized through the greater $\mathrm{N}$ demand and functional traits of beech (e.g., thinner cuticle, more pronounced leaf-wettability, higher nitrate reductase activity) compared to coniferous trees (Harrison et al. 2000). However, the opposite was observed in Hainich-Dün, indicating that the regional $\mathrm{N}$ status had a profound effect on functional traits of the dominant tree species (region $\times$ forest type in Table 5). Norway spruce forests are known to be more susceptible to $\mathrm{N}$ saturation resulting in greater $\mathrm{N}$ leaching than from deciduous forests and thus having a more open $\mathrm{N}$ cycle (Neary and Gizyn 1994; Augusto et al. 2002; Rothe et al. 2002; De Schrijver et al. 2007; Berger et al. 2009). In Hainich-Dün, the regional susceptibility to $\mathrm{N}$ saturation because of the soil fertility and the more open $\mathrm{N}$ cycle of spruce forests could have added up and overcome the positive feedback of the larger surface area of spruce on canopy $\mathrm{N}$ retention while the opposite was observed in Schwäbische Alb and Schorfheide-Chorin under N scarcity. Only marginal effects of management intensity in terms of stand density on canopy $\mathrm{N}$ retention were observed, but these seemed to differ between deciduous and coniferous forests in our study (Table 5).

\subsection{The role of plant diversity for canopy $\mathrm{N}$ retention}

We showed, to our knowledge for the first time, a biodiversity effect on aboveground nutrient cycling in forests. In the studied forests which are representative for large parts of Central Europe, plant diversity explained a significant fraction of the variance of the canopy budget of $\mathrm{TN}$ and canopy $\mathrm{N}$ retention was positively related to the diversity of trees and shrubs. We highlight that the diversity of all canopyforming plants of forests and not only that of trees impact the canopy budget of $\mathrm{TN}$ and therefore the biodiversity-ecosystem function relationship. However, because of confounding effects of region, forest type, and possibly associated species composition, the influence of the tree and shrub diversity on canopy $\mathrm{N}$ retention varied by region and forest type.

The Shannon index of shrubs and trees explained $14 \%$ of the variance in the canopy budget of TN but also interacted with the study region and the forest type, respectively ( $\mathrm{Ta}-$ ble 5). Furthermore, canopy $\mathrm{N}$ retention increased significantly with the Shannon index because not accounting for the effect of plant diversity would have resulted in an overestimation of the canopy budget of TN (Fig. 3). The fact that the strength of this relation differed by region and forest type (interaction terms in Table 5) highlights the relevance of environmental variability for the functional role of biodiversity in forest ecosystems.

Most studies on the biodiversity-nutrient cycling relationship were conducted in grassland systems. The more efficient use of $\mathrm{N}$ with increasing diversity of grassland plant species is commonly attributed to belowground complementary use of resources (Hooper and Vitousek 1998; Scherer-Lorenzen et al. 2003). Thus, the effect of the diversity of canopy-forming plant species on canopy $\mathrm{N}$ retention suggests complementary use of bulk and fine particulate deposited $\mathrm{N}$ in aboveground plant parts in Central European forests.

Similar to grasslands and belowground com- 


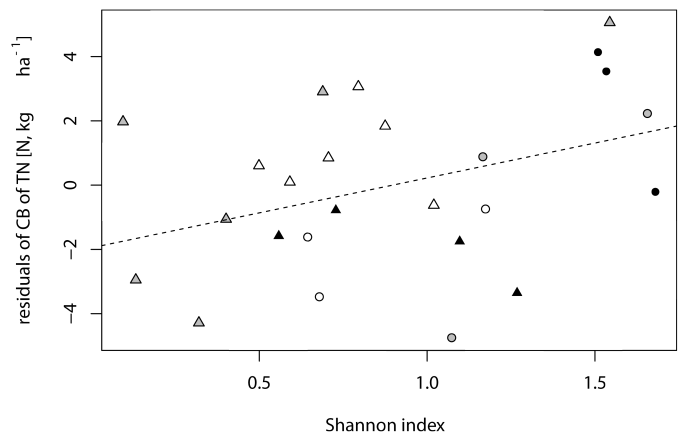

Fig. 3: Relationship of the Shannon index and the residual canopy budget of total dissolved $\mathrm{N}(\mathrm{TN})$ of the growing season 2010 after accounting for the effects of region, forest type, and basal area, respectively. According to Table 5 this effect is significant at the $P<0.001$ level. Open, black, and gray symbols refer to plots from Schwäbische Alb, Hainich-Dün, and Schorfheide-Chorin, respectively. Circles and triangles refer to coniferous and deciduous forests, respectively. The dashed line is the regression line.

plementary $\mathrm{N}$ use, aboveground complementarity in forests may result from spatial, temporal and functional niche partitioning, respectively (Tilman et al. 1996; Kahmen et al. 2006). In the context of canopy $\mathrm{N}$ retention in forests, spatial niche partitioning evolves most likely from canopy layering. When $\mathrm{N}$ is deposited, it comes first into contact with the tree canopy layer and is partially assimilated by foliage, twigs, and bark. Residual N, N falling directly through gaps of the overstorey, and $\mathrm{N}$ released from the overstorey, is translocated from the overstorey to the understorey of the canopy with the percolating water where further uptake may occur. Although the understorey vegetation has a much lower biomass than trees in Central European forests, $\mathrm{N}$ incorporation from throughfall can be twice that of overstorey trees (Gebauer et al. 2000).

Canopy $\mathrm{N}$ retention is greatest in the physiologically active season of the year (Harrison et al. 2000; Adriaenssens et al. 2012) when plant $\mathrm{N}$ demand is high. Complementary phenological species traits could therefore have low- ered temporal variation in canopy $\mathrm{N}$ retention. Since shrub diversity exceeded tree diversity (Table 3), temporal variability of $\mathrm{N}$ demand was likely greater in the understorey. Temporal complementarity might also have been related to micro-climatic differences between the canopy layers (e.g., higher relative humidity of the air near the ground sustaining water-films on canopy surfaces, thus supporting foliar uptake) or variation of $\mathrm{N}$ availability in soil and species-specific rooting depths.

Functional complementarity likely results from plant functional traits such as leaf-wettability or preference for certain $\mathrm{N}$ species and thus relates to different $\mathrm{N}$ use strategies among plant functional groups (Kahmen et al. 2006). Because of the greater species richness, functional diversity should be greater in the shrub layer than in the tree layer. Therefore, especially canopy $\mathrm{N}$ uptake in coniferous forests of Schwäbische Alb and Schorfheide-Chorin could have been supported by $\mathrm{NO}_{3}^{-}-\mathrm{N}$ uptake in the shrub layer since the capability of conifers to use $\mathrm{NO}_{3}^{-}$is low. Furthermore, species dominance can correlate with $\mathrm{N}$ species preference (McKane et al. 2002). This suggests, that the plants in the understorey could have adapted to high $\mathrm{NO}_{3}^{-}$availability in throughfall after $\mathrm{NH}_{4}^{+}$has been filtered out by conifers. This could also have coupled back to species composition in the understorey by increasing the abundance of species efficient in foliar uptake of $\mathrm{NO}_{3}^{-}$.

The interactions of the influences of region and forest type with the Shannon index on canopy budgets of TN suggested that the biodiversityecosystem functioning relationship depended on the regional and forest management-related species pools which determine the potential extent of temporal, spatial and functional complementarity. However, the abundance of key species can have a pronounced influence on apparent biodiversity effects (Wardle 1999). The influence of key species cannot be tested in forests because single species interactions are not thoroughly replicated. More research on the influence of environmental variability and forest management 
on the biodiversity-ecosystem function relationship is needed to draw conclusions on involved mechanisms.

\section{Conclusions}

We conclude that the diversity of canopyforming plants is a control of the canopy budget of TN in Central European forests and especially diverse understoreys may support canopy $\mathrm{N}$ retention and thus provided evidence for a relationship of plant diversity and nitrogen cycling in forests. However, the regional N status, the forest type, and interactions of both codetermine canopy $\mathrm{N}$ retention and couple back to the effect of plant diversity on canopy $\mathrm{N}$ retention. Hence, we showed for the first time that the traditional view of belowground complementarity of nutrient uptake by plant roots can be transferred to forest canopies, the 'roots in the sky'.

\section{Acknowledgements}

We thank the managers of the three exploratories, Swen Renner, Sonja Gockel, Kerstin Wiesner, and Martin Gorke for their work in maintaining the plot and project infrastructure; Simone Pfeiffer and Christiane Fischer giving support through the central office, Michael Owonibi for managing the central data base, and Eduard Linsenmair, Dominik Hessenmöller, Jens Nieschulze, Daniel Prati, Ingo Schöning, François Buscot and the late Elisabeth Kalko for their role in setting up the Biodiversity Exploratories project. The work has been funded by the DFG Priority Program 1374 "Infrastructure-Biodiversity-Exploratories" (Mi 927/2-2, Si 1106/4-2, Wi1601/12-2). Field work permits were issued by the responsible state environmental offices of BadenWürttemberg, Thüringen, and Brandenburg (according to $\S 72 \mathrm{BbgNatSchG).}$

\section{References}

Aber J., McDowell W., Nadelhoffer K., Magill A., Berntson G., Kamakea M., McNulty S., Currie W., Rustad L. and Fernandez I. 1998. Nitrogen Saturation in Temperate Forest Ecosystems. Hypothesis revisited. BioScience 48:921-934.

Adriaenssens S., Staelens J., Wuyts K., Samson R., Verheyen K. and Boeckx P. 2012. Retention of Dissolved Inorganic Nitrogen by Foliage and Twigs of Four Temperate Tree Species. Ecosystems 15:1093-1107. doi:10.1007/s10021-012-9568-5.

Augusto L., Ranger J., Binkley D. and Rothe A. 2002. Impact of several common tree species of European temperate forests on soil fertility. Ann. For. Sci. 59:223-253. doi:10.1051/forest:2002020.

Berger T.W., Inselbacher E., Mutsch F. and Pfeifer M. 2009. Nutrient cycling in eighteen pure and mixed stands of beech (Fagus sylvatica) and spruce (Picea abies). For. Ecol. Manage. 258:2578-2592. doi:10.1016/j.foreco.2009.09.014.

Boch S., Prati D., Müller J., Socher S., Baumbach H., Buscot F., Gockel S., Hemp A., Hessenmöller D., Kalko E.K., Linsenmair K.E., Pfeiffer S., Pommer U., Schöning I., Schulze E.D., Seilwinder C., Weisser W.W., Wells K. and Fischer M. 2013. High plant species richness indicates management-related disturbances rather than the conservation status of forests. Basic Appl. Ecol. 14:496-505. doi:10.1016/j.baae.2013.06.001.

Dail D.B., Hollinger D.Y., Davidson E.A., Fernandez I., Sievering H.C., Scott N.A. and Gaige E. 2009. Distribution of nitrogen-15 tracers applied to the canopy of a mature spruce-hemlock stand, Howland, Maine, USA. Oecologia 160:589-599. doi:10.1007/s00442-009-1325-x.

De Schrijver A., Geudens G., Augusto L., Staelens J., Mertens J., Wuyts K., Gielis L. 
and Verheyen K. 2007. The effect of forest type on throughfall deposition and seepage flux: a review. Oecologia 153:663-674. doi:10.1007/s00442-007-0776-1.

Eilers G., Brumme R. and Matzner E. 1992. Aboveground $\mathrm{N}$-uptake from wet deposition by Norway spruce (Picea abies Karst.). For. Ecol. Manage. 51:239-249. doi:10.1016/03781127(92)90489-V.

FAO. 2011. State of the World's Forests. Food and Agricultural Organisation of the United Nations, Rome, Italy.

Fischer M., Bossdorf O., Gockel S., Hänsel F., Hemp A., Hessenmöller D., Korte G., Nieschulze J., Pfeiffer S., Prati D., Renner S., Schöning I., Schumacher U., Wells K., Buscot F., Kalko E.K.V., Linsenmair K.E., Schulze E.D. and Weisser W.W. 2010. Implementing large-scale and long-term functional biodiversity research: The Biodiversity Exploratories. Basic Appl. Ecol. 11:473-485. doi:10.1016/j.baae.2010.07.009.

Gaige E., Dail D., Hollinger D., Davidson E., Fernandez I., Sievering H., White A. and Halteman W. 2007. Changes in Canopy Processes Following Whole-Forest Canopy Nitrogen Fertilization of a Mature SpruceHemlock Forest. Ecosystems 10:1133-1147. doi:10.1007/s10021-007-9081-4.

Galloway J.N., Dentener F.J., Capone D.G., Boyer E.W., Howarth R.W., Seitzinger S.P., Asner G.P., Cleveland C.C., Green P.A., Holland E.A., Karl D.M., Michaels A.F., Porter J.H., Townsend A.R. and Vorosmarty C.J. 2004. Nitrogen cycles: past, present, and future. Biogeochemistry 70:153-226. doi:10.1007/s10533-004-0370-0.

Garten Jr. C.T. and Hanson P.J. 1990. Foliar retention of ${ }^{15} \mathrm{~N}$-nitrate and ${ }^{15} \mathrm{~N}$-ammonium by red maple (Acer rubrum) and white oak (Quercus alba) leaves from simulated rain. Environ. Exp. Bot. 30:333-342.

Gebauer G., Zeller B., Schmidt G., May C., Buchmann N., Colin-Belgrand M., Dambrine E., Martin F., Schulze E.D. and Bottner
P. 2000. The fate of ${ }^{15} \mathrm{~N}$-labelled nitrogen inputs to coniferous and broadleaf forests. In: E.D. Schulze (ed.), Carbon and nitrogen cycling in European Forest Ecosystems, Ecol. Stud., vol. 142, chap. 7, pp. 144-170. Springer, Berlin, Heidelberg, New York.

Harrison A., Schulze E.D., Gebauer G. and Bruckner G. 2000. Canopy uptake and utilization of atmospheric pollutant nitrogen. In: E.D. Schulze (ed.), Carbon and nitrogen cycling in European Forest Ecosystems, Ecol. Stud., vol. 142, chap. 8, pp. 171-188. Springer, Berlin, Heidelberg, New York.

Hooper D.U. and Vitousek P.M. 1998. Effects of plant composition and diversity on nutrient cycling. Ecol. Monogr. 68:121-149. doi: $10.2307 / 2657146$.

Horn R., Schulze E.D. and Hantschel R. 1989. Nutrient Balance and Element Cycling in Healthy and Declining Norway Spruce Stands. In: E.D. Schulze, O.L. Lange and R. Oren (eds.), Forest decline and air Pollution: A Study of Spruce (Picea abies) on Acid Soils, Ecol. Stud., vol. 77, chap. 4-I, pp. 444-458. Springer, Berlin, Heidelberg.

IUSS Working group WRB. 2006. Guidelines for soil description. 4th edn. Food and Agricultural Organisation of the United Nations, Rome, 116 pp.

Kahmen A., Renker C., Unsicker S.B. and Buchmann N. 2006. Niche complementarity for nitrogen: An explanation for the biodiversity and ecosystem functioning relationship? Ecology 87:1244-1255. doi:10.1890/00129658(2006)87[1244:NCFNAE]2.0.CO;2.

Kelty M. 2006. The role of species mixtures in forest plantations. For. Ecol. Manage. 233:195-204. doi:10.1016/j.foreco.2006.05.011.

Lockwood A.L., Filley T.R., Rhodes D. and Shepson P.B. 2008. Foliar uptake of organic nitrates. Geophys. Res. Lett. 35:L15809. doi:10.1029/2008GL034714. 
Lovett G. and Lindberg S.E. 1993. Atmospheric deposition and canopy interactions of nitrogen in forests. Can. J. For. Res. 23:16031616.

McKane R.B., Johnson L.C., Shaver G.R., Nadelhoffer K.J., Rastetter E.B., Fry B., Giblin A.E., Kielland K., Kwiatkowski B.L., Laundre J.A. and Murray G. 2002. Resourcebased niches provide a basis for plant species diversity and dominance in arctic tundra. Nature 415:68-71. doi:10.1038/415068a.

Millennium Ecosystem Assessment. 2005. Ecosystems and human well-being: Synthesis. Millennium Ecosystem Assessment series. Island Press, Washington D.C., 155 pp.

Morin X., Fahse L., Scherer-Lorenzen M. and Bugmann H. 2011. Tree species richness promotes productivity in temperate forests through strong complementarity between species. Ecol. Lett. 14:1211-1219. doi:10.1111/j.1461-0248.2011.01691.x.

Neary A. and Gizyn W. 1994. Throughfall and stemflow chemistry under deciduous and coniferous forest canopies in south-central Ontario. Can. J. For. Res. 24:1089-1100.

Nordin U. 1991. Acid deposition and throughfall fluxes of elements as related to tree species in deciduous forests of south Sweden. For. Ecol. Manage. 60:209-230.

Papen H., Gessler A., Zumbusch E. and Renneberg H. 2002. Chemolithoautotrophic nitrifiers in the phyllosphere of spruce ecosystem receiving high atmospheric $\mathrm{N}$ input. Curr. Microbiol. 44:56-60.

Paquette A. and Messier C. 2011. The effect of biodiversity on tree productivity: from temperate to boreal forests. Glob. Ecol. Biogeogr. 20:170-180. doi:10.1111/j.14668238.2010.00592.x.

Peuke A.D., Jeschke W.D., Dietz K.J., Schreiber L. and Hartung W. 1998. Foliar application of nitrate or ammonium as sole nitrogen supply in Ricinus communis - I. Carbon and nitrogen uptake and inflows. New
Phytol. 138:675-687. doi:10.1046/j.14698137.1998.00158.x.

R Development Core Team. 2011. R: A Language and Environment for Statistical Computing. R Foundation for Statistical Computing, Vienna, Austria.

URL http://www.R-project.org/

Rennenberg H., Kreutzer K., Papen H. and Weber P. 1998. Consequences of high loads of nitrogen for spruce (Picea abies) and beech (Fagus sylvatica) forests. New Phytol. 139:71-86. doi:10.1046/j.14698137.1998.00181.x.

Rothe A., Huber C., Kreutzer K. and Weis W. 2002. Deposition and soil leaching in stands of Norway spruce and European Beech: Results from the Höglwald research in comparison with other European case studies. Plant Soil 240:33-45.

Sala O.E., Chapin F.S., Armesto J.J., Berlow E., Bloomfield J., Dirzo R., Huber-Sanwald E., Huenneke L.F., Jackson R.B., Kinzig A., Leemans R., Lodge D.M., Mooney H.A., Oesterheld M., Poff N.L., Sykes M.T., Walker B.H., Walker M. and Wall D.H. 2000. Global biodiversity scenarios for the year 2100. Science 287:1770-1774. doi:10.1126/science.287.5459.1770.

Scherer-Lorenzen M., Körner C. and Schulze E.D. 2005. The Functional Significance of Forest Diversity: A Synthesis. In: M. Scherer-Lorenzen, C. Körner and E.D. Schulze (eds.), Forest Diversity and Function, Ecological Studies, vol. 176, pp. 377-389. Springer Berlin Heidelberg. doi:10.1007/3-540-26599-6_17.

Scherer-Lorenzen M., Palmborg C., Prinz A. and Schulze E.D. 2003. The role of plant diversity and composition for nitrate leaching in grasslands. Ecology 84:1539-1552. doi:10.1890/00129658(2003)084[1539:TROPDA]2.0.CO;2.

Schmitz F., Polley H. and Schwitzgebel F. 2004. Die zweite Bundeswaldinventur - $B W I^{2}-$ Der Inventurbericht. Bundesministerium für 
Ernährung, Landwirtschaft und Verbraucherschutz, Bonn, Germany, 231 pp.

Schwarz M.T., Oelmann Y. and Wilcke W. 2011. Stable N isotope composition of nitrate reflects $\mathrm{N}$ transformations during the passage of water through a montane rain forest in Ecuador. Biogeochemistry 102:195208. doi:10.1007/s10533-010-9434-5.

Sievering H., Tomaszewski T. and Torrizo J. 2007. Canopy uptake of atmospheric $\mathrm{N}$ deposition at a conifer forest: Part I -canopy $\mathrm{N}$ budget, photosynthetic efficiency and net ecosystem exchange. Tellus B 59:483-492. doi:10.1111./j.1600-0889.2007.00264.x.

Sparks J.P., Roberts M. and Monson R.K. 2003. The uptake of gaseous organic nitrogen by leaves: A significant global nitrogen transfer process. Geophys. Res. Lett. 30:2189. doi:10.1029/2003GL018578.

Symstad A.J., Chapin III F.S., Wall D.H., Gross K.L., Huenneke L.F., Mittelbach G.G., Peters D.P.C. and Tilman D. 2003. Long-term and Large-scale perspectives on the relationship between biodiversity and ecosystem Functioning. BioScience 53:89-98. doi:10.1641/00063568(2003)053[0089:LTALSP]2.0.CO;2.

Tilman D., Wedin D. and Knops J. 1996. Productivity and sustainability influenced by biodiversity in grassland ecosystems. Nature 379:718-720. doi:10.1038/379718a0.

Ulrich B. 1983. Interactions of forest canopies with atmospheric constituents: $\mathrm{SO}_{2}$, alkali and earth alkali cations and chloride. In: B. Ulrich and J. Pankrath (eds.), Effects of accumulation of air pollutants in forest ecosystems, pp. 33-45. D. Reidel Publishing, The Netherlands.

Vila M., Vayreda J., Comas L., Ibanez J.J., Mata T. and Obon B. 2007. Species richness and wood production: a positive association in Mediterranean forests. Ecol. Lett. 10:241250. doi:10.1111/j.1461-0248.2007.01016.x.
Vila M., Vayreda J., Gracia C. and Ibanez J. 2003. Does tree diversity increase wood production in pine forests? Oecologia 135:299 303. doi:10.1007/s00442-003-1182-y.

Wardle D.A. 1999. Is "sampling effect" a problem for experiments investigating biodiversity-ecosystem function relationships? Oikos 87:403-407. doi: $10.2307 / 3546757$. 